\title{
Nutrient and sediment losses to streams after intervention of Eucalyptus plantations
}

\author{
Jaime G. Cuevas ${ }^{1,2,3 *}$, Christian Little ${ }^{4,5}$, David $\operatorname{Lobos}^{5}$, Antonio Lara ${ }^{5,6}$, Mario Pino 7 , \\ Antonia Acuña ${ }^{8}$
}

${ }^{1}$ Centro de Estudios Avanzados en Zonas Áridas (CEAZA), Av. Raúl Bitrán 1305, La Serena, Chile. ${ }^{2}$ Universidad Austral de Chile, Instituto de Ingeniería Agraria y Suelos, Valdivia, Chile. ${ }^{3}$ Universidad Austral de Chile, Centro de Investigacion en Suelos Volcánicos (CISVo), Valdivia, Chile. ${ }^{4}$ Instituto Forestal (INFOR), Sede Los Ríos, Fundo Teja Norte s/n, Valdivia, Chile. ${ }^{5}$ Center for Climate and Resilience Research $(C R)^{2}$, Valdivia, Chile. ${ }^{6}$ Universidad Austral de Chile, Facultad de Ciencias Forestales y Recursos Naturales, Valdivia, Chile. ${ }^{7}$ Universidad Austral de Chile, Instituto de Ciencias de la Tierra and TAQUACH, Valdivia, Chile. ${ }^{8}$ Laboratorio de Biodiversidad y Ecología del Dosel, Instituto de Conservación, Biodiversidad y Territorio ICBTe, Facultad de Ciencias Forestales y Recursos Naturales, Universidad Austral de Chile, Valdivia, Chile ${ }^{*}$ Corresponding author: jxcuevas@ceaza.cl.

\begin{abstract}
The forestry industry is known for negatively affecting stream quality when proper management is not applied. Nutrient retention by soils and streamside vegetation buffer strips could attenuate these impacts. We tested the response of different streams to the nutrients and sediments released by a) fertilization and b) clear-cutting of Eucalyptus globulus plantations growing on volcanic soils in southern Chile. We expected the exports to decrease as the remnant streamside native forest width (SNFW) increased. The response to fertilization was restricted to the days immediately after the nutrient addition. On the contrary, most of the nutrients analysed (nitrate, ammonium, dissolved organic nitrogen, phosphate, and total phosphorus) showed a long-term response to clear-cutting. The observed trends were not affected by the SNFWs included in this study (2.5-22 m). Regarding sediments, there were no differences compared to the control watershed, probably due to improvements in the implemented management practices. We conclude that a SNFW $<22 \mathrm{~m}$ is not sufficient to avoid the loss of nutrients released by clear-cutting, as it is for sediments. The analysed SNFWs were smaller than those established by Chilean regulations (maximum $30 \mathrm{~m}$ ) and our results support claims for wider riparian widths in order to effectively filter the nutrients and sediments that influence streams.
\end{abstract}

Keywords: Eucalyptus globulus, fertilization, sediments, streamside native forest width, Ultisols. 


\section{Introduction}

Forestry can adversely impact soil and stream water quality when it is not managed appropriately. For example, clear-cutting can cause soil loss that is exported into streams as sediment during the construction of roads for harvest (Huber, 2009; Frêne, 2010). When the harvest is carried out close to riverbanks, stream bank erosion produces a larger input of organic matter and nutrients into streams, favouring the productivity of aquatic organisms (Thompson et al., 2009). Loss of forest cover also decreases nutrient uptake, making more nutrients available for leaching into streams (Thompson et al., 2009). Fertilization at rates higher than those required by trees may also cause nutrient losses to the environment as a whole (Beltran et al., 2010). These changes impair the exceptional water quality associated with either native forests or old plantations (Hedin et al., 1995; Baillie and Neary, 2015). As precipitation decreases in many parts of the world (IPCC, 2007), the supply of quality water required to meet human demands will be in jeopardy; thus any environmental practice that conserves this resource is essential for modern society (Jones et al., 2016).

Site conditions where forestry activities are carried out can mitigate negative effects. For example, the role of soils in nutrient filtering has been previously highlighted, especially in those originated from volcanic ash. This is due to a tight nitrogen $(\mathrm{N})$ cycle (Huygens et al., 2008) with scarce inorganic $\mathrm{N}$ losses to streams (Hedin et al., 1995), high phosphorus adsorption due to the aluminum and hydrous oxide composition in amorphous clays (Alfaro et al., 2008; Fleige et al., 2016), and high cationic exchange capacity asso- ciated to crystalline clays and the organic matter accumulation that predominates in riparian soils (Huertas et al., 2016).

Several studies have also shown that the maintenance of native or exotic riparian vegetation (RV) along streamsides can buffer the negative changes caused by forest operations (Brosofske et al., 1997; Quinn et al., 2004; Boothroyd et al., 2004; Baillie and Neary, 2015). Furthermore, increasing riparian widths has proven to increase stream protection regarding different biological and physical-chemical properties (Brosofske et al., 1997; Little et al., 2015). Even though previous studies provide important information, most of them have used a comparative approach between catchments with/without RV or with different land covers (i.e., native forest versus exotic plantations), studying their influence on stream properties (the referencedifference method; Quinn et al., 1997; Cuevas et al., 2006; Quinn and Wright-Stow, 2008). This 'static' approach is usually carried out in watersheds that differ in relation to the factor under consideration (the land cover), nonetheless, since the other factors (e.g., geomorphology, soils) are not identical, a potential for confounding variables exists when analysing results. Since some watersheds were studied only after a clear-cut occurred (sometimes months or years afterwards), this type of analysis may not be capable of detecting transient effects that can be observed days or weeks after tree removal. Even though other researchers have studied patterns in the same watersheds before and after forest intervention, monitoring may not have occurred until months or even years after the disturbance (e.g., Brosofske et al., 1997; Quinn 
et al., 2004; Boothroyd et al., 2004). Few studies have maintained a high frequency record of stream properties before/after clear-felling (Huber, 2009; Frêne, 2010; Rodgers et al., 2011).

Our objective was to monitor the same micro-watersheds before, during, and after a plantation fertilization and harvest, providing a detailed evaluation of the temporal dynamics of the nutrient and sediment losses under varying RV widths. Our hypothesis points out that when RV width increases, stream quality must show a lower variation after either plantation fertilization or clear-cutting. Concurrently, we monitored a control watershed that was not intervened. Thus, our 'dynamic' approach was a combination of the reference-difference method and the before/after approach. The response variables selected include the principal nutrients that influence plant growth and aquatic productivity (Thompson et al., 2009), while sediments were analysed since they are an indicator of soil erosion (Rodgers et al., 2011). Moreover, losses of nutrients such as nitrogen and phosphorus are important indicators of the status of the biogeochemical cycles in soil and water, and they represent an intermediate link between ecosystem disturbances and the response of stream biological communities (Thompson et al., 2009). In this regard, nutrients have not been previously evaluated with this dual methodological approach.

\section{Materials and Methods}

\subsection{General location and site description}

The selected study area is located in the Chilean Valdivian Rainforest Ecoregion. This region has not been impacted by chronic air pollution and is one of the most pristine areas worldwide, with extremely low atmospheric $\mathrm{N}$ deposition and nutrient concentrations in stream water (Hedin et al., 1995; Perakis and Hedin, 2002). We studied five forested headwater catchments located within the Reserva Costera Valdiviana (RCV) (Figure 1). Between 1993 and 1999, 3000 ha of native forests in this area were clear-cut, burned, and converted into exotic Eucalyptus globulus plantations (Little et al., 2015).

The five watersheds are located at $39^{\circ} 58^{\prime} \mathrm{S}$, $73^{\circ} 33^{\prime} \mathrm{W}$ (Figure 1). Elevations range from 6 to $195 \mathrm{~m}$ a.s.1. The mean annual long-term (19602010) rainfall near the site (recorded in the city of Valdivia) is $2,300 \mathrm{~mm}$. This area also has a humid temperate climate with a Mediterranean influence. Rainfall is concentrated mainly between June and August. Summer (January-March) rainfall is limited, representing $<10 \%$ of the annual value (Little et al., 2015); snowfall is rare.

The studied watersheds are located in the Coastal Range of Chile, which is composed of Paleozoic metamorphic rocks, partially overlaid by Tertiary marine sediments with a slope of $30^{\circ}$. In the western zone of RCV, outcrops of granitic intrusions from the Cretaceous period can be found (Sernageomin, 1982). Soils have a volcanic origin and are Typic Haplohumults (Ultisols, Hueycolla series; CIREN, 2001), with a low $\mathrm{pH}(4.2-4.8),<$ $3 \mathrm{mg} \mathrm{kg}^{-1}$ of $\mathrm{Ca}(\mathrm{OH})_{2}$-extractable $\mathrm{NO}_{3}^{-}-\mathrm{N}$ and $\mathrm{Ol}-$ sen-P, with a high $\mathrm{Al}$ concentration and saturation ( $>2 \mathrm{cmol}^{+} \mathrm{kg}^{-1}$ and $>44 \%$, respectively). Nutrient values are generally lower than those corresponding to more productive volcanic soils in the region (Huertas et al., 2016). 


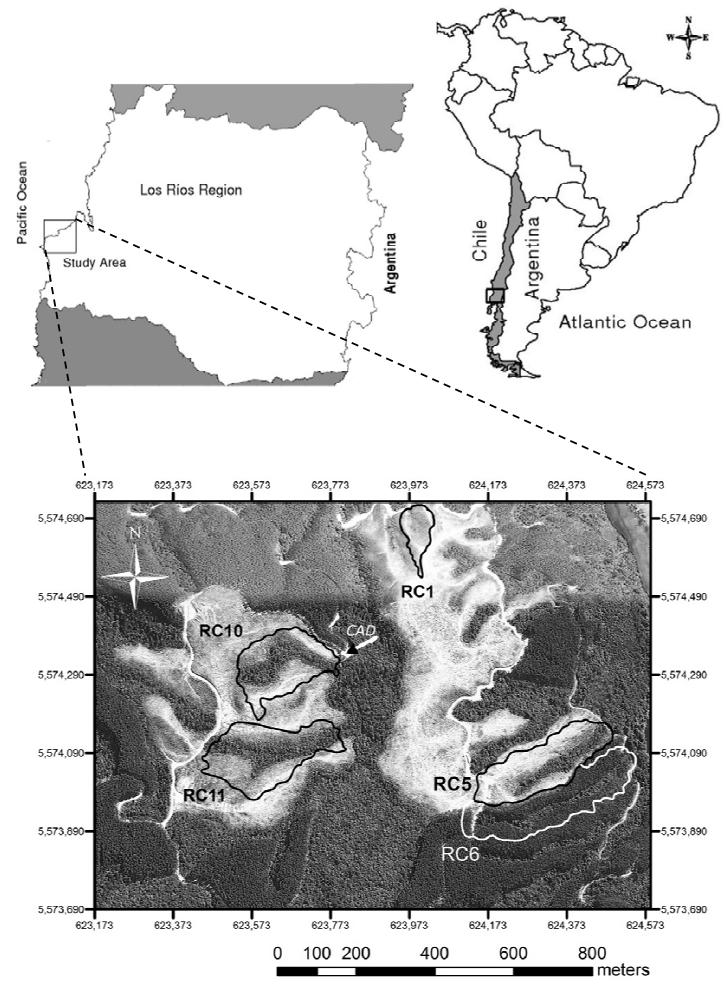

Figure 1. Location of the experimental watersheds in the Reserva Costera Valdiviana, Los Ríos Region, southern Chile. Picture from January 2013 after the clear-cutting of Eucalyptus plantations. The native riparian vegetation is clearly seen through the middle of the harvested watersheds, and with a lighter colour in the control catchment (RC6). Streams flow eastwards, except for RC1 (northwards). CAD refers to the Cadillal pluviometer station, while the Administration station was located c. $2.4 \mathrm{~km}$ northwest of RC10.

\subsection{Watershed characteristics and land cover}

The selected micro-watersheds ranged in size from 0.85 to 5.26 ha (Table 1$)$. They were categorized into two land cover types: (a) native forest, considering strips of differing widths along the main stream's channel (SNFW) and (b) 13-year-old (in 2008) fastgrowing exotic E. globulus plantations located in the remaining portion of the watersheds. The minimum
SNFW at each side of the stream was $2.5 \mathrm{~m}(\mathrm{RC} 1)$, and the maximum was $22.5 \mathrm{~m}$ in RC10 (Table 1). These widths represent native forest remnants from past forest interventions that replaced the native cover with E. globulus. Plantations had a density of 1,300 to 1,700 trees $\mathrm{ha}^{-1}$. This was the dominant land use in all of the watersheds ranging from $63 \%$ in $\mathrm{RC} 10$ to $98.7 \%$ in RC1, expressed as the percentage cover over the total watershed area (Table 1). 
Table 1. Watershed characteristics and treatment dates.

\begin{tabular}{|c|c|c|c|c|c|c|c|c|c|c|}
\hline \multirow[b]{2}{*}{ Code } & \multirow[b]{2}{*}{$\begin{array}{l}\mathrm{SNFW}^{(\mathrm{a})} \\
(\mathrm{m})\end{array}$} & \multirow[b]{2}{*}{$\begin{array}{c}\text { Area } \\
\text { (ha) }\end{array}$} & \multicolumn{3}{|c|}{ Eucalyptus cover } & \multirow[b]{2}{*}{$\begin{array}{l}\text { Elevation } \\
\text { range } \\
\text { (m a.s.l.) }\end{array}$} & \multirow[b]{2}{*}{$\begin{array}{c}\text { Mean } \\
\text { transversal } \\
\text { slope }(\%)\end{array}$} & \multirow[b]{2}{*}{$\begin{array}{l}\text { Date of } \\
\text { fertilization } \\
\text { (year 2009) }\end{array}$} & \multirow[b]{2}{*}{$\begin{array}{c}\text { Start of } \\
\text { harvest } \\
\text { (year 2011) }\end{array}$} & \multirow[b]{2}{*}{$\begin{array}{c}\text { End of } \\
\text { harvest } \\
\text { (year 2011) }\end{array}$} \\
\hline & & & $\begin{array}{c}\% \\
\text { cover }\end{array}$ & $\begin{array}{l}\text { Mean } \\
\text { height } \\
(\mathrm{m})\end{array}$ & $\begin{array}{l}\text { Mean } \\
\text { DBH }^{(b)} \\
(\mathrm{cm})\end{array}$ & & & & & \\
\hline $\mathrm{RC} 1$ & 2.5 & 0.85 & 98.7 & 16.0 & 15.2 & $46-88$ & 34.4 & October $19^{\text {th }}$ & March $31^{\text {th }}$ & April $30^{\text {th }}$ \\
\hline RC5 & 14.8 & 3.74 & 76.1 & 22.4 & 19.1 & $6-107$ & 46.6 & November $2^{\text {nd }}$ & April $12^{\text {nd }}$ & April $30^{\text {th }}$ \\
\hline RC6 & 14.6 & 5.26 & 69.4 & 17.9 & 12.0 & $6-124$ & 45.2 & Control & Control & Control \\
\hline $\mathrm{RC} 10$ & 22.5 & 3.43 & 63.1 & 15.0 & 20.0 & $116-164$ & 41.0 & October $20^{\text {th }}$ & February $24^{\text {th }}$ & April $5^{\text {th }}$ \\
\hline $\mathrm{RC} 11$ & 17.2 & 4.28 & 74.8 & 17.8 & 15.2 & $115-195$ & 42.7 & November $4^{\text {th }}$ & February $18^{\text {th }}$ & April $30^{\text {th }}$ \\
\hline
\end{tabular}

(a) SNFW: Streamside native forest width at each side of the stream.

(b) $\mathrm{DBH}$ : diameter at breast height

The native forests in this area were quite similar throughout the studied catchments, composed of evergreen broadleaved tree species that were young, but multi-aged with several strata. We found 26 tree species; the most common were Amomyrtus luma and Drimys winteri. The understories were rich in shrubs, herbs, vines, epiphytes, and mosses. Tree height varied between 15 and $20 \mathrm{~m}$, with emergent individuals of Nothofagus dombeyi (a low density tree) reaching $25 \mathrm{~m}$. Small diameters, at breast height (DBH) predominated, with few larger individuals more than $35 \mathrm{~cm}$ in DBH. The disturbance status of the riparian strips varied, with sectors of dense cover of trees, shrubs, herbs, and epiphytes, and other sectors dominated by the ferns Lophosoria quadripinnata, Blechnum chilense, and the Chusquea quila bamboo, typical of anthropogenic disturbances.

The mean slope perpendicular to the stream fluctuated between 34 and $47 \%$ depending on the watershed (Table 1); most of them had principally eastern exposure, with the exception of RC1 (northern exposure).

\subsection{Rainfall-runoff monitoring and computing}

Precipitation was recorded during four hydrological years (April 2008 to June 2012) using two HOBO ${ }^{\circledR}$ Event $\mathrm{H}-07-002-04$ tipping bucket rain gauges located in open areas (Onset Computer Corporation, Bourne, MA, USA). One of these was located near the watersheds (named Cadillal station, $113 \mathrm{~m}$ a.s.1., Figure 1), and another one in the RCV Headquarters (referred to as the Administration station, $16 \mathrm{~m}$ a.s.l). Precipitation resolution per event was $0.2 \mathrm{~mm}$.

Runoff was monitored using $90^{\circ} \mathrm{V}$-notch weirs installed in each catchment outlet. Streamflow was derived from $\mathrm{HOBO}{ }^{\circledR}$ pressure sensors (U20-001-01), using a 15-min resolution. The recorded water depths were converted into discharges by directly calibrating with jar and chronometer measurements, where both variables were related through power functions. The rainfall/runoff coefficient (RR) was calculated by dividing the accumulated discharge of a given period by the accumulated rainfall in the same period, and then dividing the result by the watershed area. 


\subsection{Experimental treatments}

All of the watersheds, except for the control RC6, were fertilized in October-November 2009 after a baseline of 15 months. We used inorganic fertilizers at rates of $\left(\mathrm{kg} \mathrm{ha}^{-1}\right) 63 \mathrm{~N}, 45 \mathrm{P}, 26 \mathrm{~K}, 50 \mathrm{Ca}, 32 \mathrm{~S}$, and $10 \mathrm{Mg}$, applied as calcareous ammonium nitrate, triple superphosphate, and $\mathrm{K}_{2} \mathrm{SO}_{4} \cdot 2 \mathrm{MgSO}_{4}$ (Sulpomag). These are the recommended rates for the fertilization of young eucalyptus trees (Schlatter J., personal communication). The fertilizer was applied by broadcast by a team of workers operating simultaneously within the same watershed on the dates shown in Table 1. Although it is not a common practice to fertilize 13 year-old plantations, the purpose of this intervention was to evaluate the possible nutrient loss after the experimental addition of nutrients to the soil at this advanced stage of plantation rotation.

Regarding the plantation harvest, once again in all of the evaluated watersheds with the exception of the control, the clear-cutting was carried out on the dates shown in Table 1 . The machinery used was a combination of feller bunchers and chainsaws operated by forestry workers. Special care was taken to harvest eucalyptus trees only, keeping streamside native riparian strips intact. Logging was carried out with grapple skidders.

\subsection{Nutrient concentrations}

Dissolved and particulate nutrients (nitrogen and phosphorus) were in general sampled every 15 days from July 2008 to June 2012, accumulating a total of 83-99 samples from the headwaters of each stream. During some periods, samples were taken every week or even more frequently (i.e., immediately after fertilization or clearcutting). Samples were taken $5 \mathrm{~m}$ upstream from the V-notch weir location, from a central point of the stream's surface. Water samples were collected in plastic bottles that had been previously washed with $5 \%$ hydrochloric acid. Bottles were rinsed with $100 \mathrm{ml}$ of water taken from the stream; bottles were capped and shaken, and the water was then discarded. Thereafter, $500 \mathrm{ml}$ samples were collected; the capped bottles were kept at cool temperatures $\left(<5^{\circ} \mathrm{C}\right)$, and the samples were frozen within 10 $\mathrm{h}$ of being collected.

The chemicals analysed included: total nitrogen $(\mathrm{N})$, total dissolved $\mathrm{N}, \mathrm{NO}_{3}{ }^{-}-\mathrm{N}$ (nitrate- $\mathrm{N}$ ), $\mathrm{NO}_{2}{ }^{-}-\mathrm{N}$ (nitrite- $\mathrm{N}$ ), $\mathrm{NH}_{4}^{+}-\mathrm{N}$ (ammonium-N), dissolved organic nitrogen (DON), particulate organic nitrogen (PON), total phosphorus ( $\mathrm{P}$ ), and $\mathrm{PO}_{4}{ }^{3-}-\mathrm{P}$ (phosphate-P). DON was calculated as the difference of the total dissolved $\mathrm{N}$ and the inorganic forms, while PON was determined as the total $\mathrm{N}$ minus the total dissolved N. Samples were analysed at the Limnology Laboratory at the Universidad Austral de Chile, following APHA (2005) procedures. Detection limits were $1 \mu \mathrm{g} \mathrm{l}^{-1}\left(\mathrm{NO}_{2}^{-}-\mathrm{N}, \mathrm{NO}_{3}^{-}-\mathrm{N}\right.$, $\mathrm{NH}_{4}^{+}-\mathrm{N}$, and $\mathrm{PO}_{4}^{3-}-\mathrm{P}$ ), $5 \mu \mathrm{g} \mathrm{l^{-1 }}$ (total $\mathrm{P}$ ), and $15 \mu \mathrm{g}$ $\mathrm{l}^{-1}$ (total $\mathrm{N}$, total dissolved $\left.\mathrm{N}\right)$.

\subsection{Sediment evaluations}

From February 2009 to August 2012 (62-70 sampling dates) we measured the cumulative suspended sediments (CSS) in the stream, an indicator of hillslope erosion and sediment delivery to streams. As described by Little et al. (2015), we used five fixed cylindrical PVC traps with heights of $10 \mathrm{~cm}$ and a height/diameter ratio of 2.85 (collecting area was thus $9.7 \mathrm{~cm}^{2}$ per trap). PVC traps were located on the bed of the V-notch weir in a parallel line to the $\mathrm{V}$ section and perpendicular to streamflow, capturing suspended solids over 15 days, which also corresponded to the sample collection frequency. During some periods samples were taken every week or even more frequently. 
The CSS device captures both organic and siliciclastic materials, ranging in size from gravel to mud. This CSS was separated according to grain size $[>2 \mathrm{~mm}$ (gravel), $2 \mathrm{~mm}-63 \mu \mathrm{m}$ (sand), $<63 \mu \mathrm{m}$ (silt-clay)] using standard sieves at Universidad Austral de Chile's Sedimentology Laboratory. The organic and inorganic portions were determined by burning them for $2 \mathrm{~h}$ at $550{ }^{\circ} \mathrm{C}$, after which they were weighed and the difference was then calculated to determine each granulometric class (Folk, 1980). Since the organic fraction corresponded to particulate organic matter, we abbreviated it as POM. The units for sediments were $\mathrm{mg}$ day $^{-1}$. To allow for a better comparison among watersheds, we divided the amount of collected material by the watershed area instead of the trap area.

\subsection{Data analyses}

Time series were constructed with nutrient and sediment data, which were compared among experimental watersheds and the control (RC6). The nutrient export $($ export $=$ concentration $*$ discharge/watershed area; units of mass time ${ }^{-1}$ area $^{-1}$ ) was used as a response variable .

Sediment loads were also expressed in mass time ${ }^{-1}$ $\operatorname{area}^{-1}$ units. However, they did not strictly represent the sediment exports of the watershed because: i) traps did not cover the entire area of the weir, and an extrapolation to the full surface does not take into account that sedimentation is not homogeneous across the weir floor (authors' observations); ii) sediment also accumulated in nonquantified magnitudes upstream of the weir, in the transition between the rocky streambed and the weir floor; iii) the amount of suspended solid that can be captured by our traps was only a portion of the total available sediment flowing through the weir, and the collection efficiency was unknown. Despite these limitations, since all of the water- sheds were sampled with the same protocol, we can consider the sediments collected as a "rough" estimator of the true export.

The rationale of our study was to analyse each watershed separately from the others, as a function of time and the experimental treatments applied. Both their dynamics and statistical significance of changes were then compared to the other catchments, both quantitatively and visually. Consequently, an Analysis of Variance (ANOVA) was used to compare within a given watershed: baseline (from the beginning of monitoring up to the last water sampling before the fertilization treatment); after fertilization (AF); and after clear-cut. To separate the duration of the effect of fertilization on water quality, the AF treatment was subdivided in two periods: three months (AF3) and 15 months (AF15) after fertilization. Except for AF3, all data groups had a similar duration (1416 months). To detect where differences were produced an Honestly Significant Difference (HSD) test for unequal sample sizes was employed following the ANOVA. Assumptions of this method were previously tested: data independence, normal distribution, and homoscedasticity. When assumptions were not met, original data were transformed using the function $\log _{10}(x+1)$. If common transformations did not resolve this issue, we applied the Kruskal-Wallis test, followed by a posteriori multiple comparisons of mean ranks for all groups. For sediments, we divided the results into two periods: before and after the clear-cutting operation. Within each watershed and for every grain size fraction analysed, we applied the Mann-Whitney test. We used a two-tailed test, which does not assume that the values observed after the clear-cutting operation must be higher than before harvest. All analyses were performed with Statistica ${ }^{\circledR} 6.0$ software (Statsoft, Inc., Tulsa, OK, USA). 


\section{Results}

\subsection{Rainfall and discharge}

Since the nutrient monitoring began in July 2008 and ended in June 2012, we expressed the precipitation on an annual basis from July of a given year to June of the following year (Figure 2). At the meteorological station located at low altitude (Administration), representative of RC1, RC5 and RC6, it rained 1380, 1526, 1441 and 1846 $\mathrm{mm}$, for the periods beginning in 2008, 2009, 2010 and 2011, respectively (Figure 2a). The year 2010 was most likely underestimated because the pluviometer was out of service between mid-September and mid-October 2010.
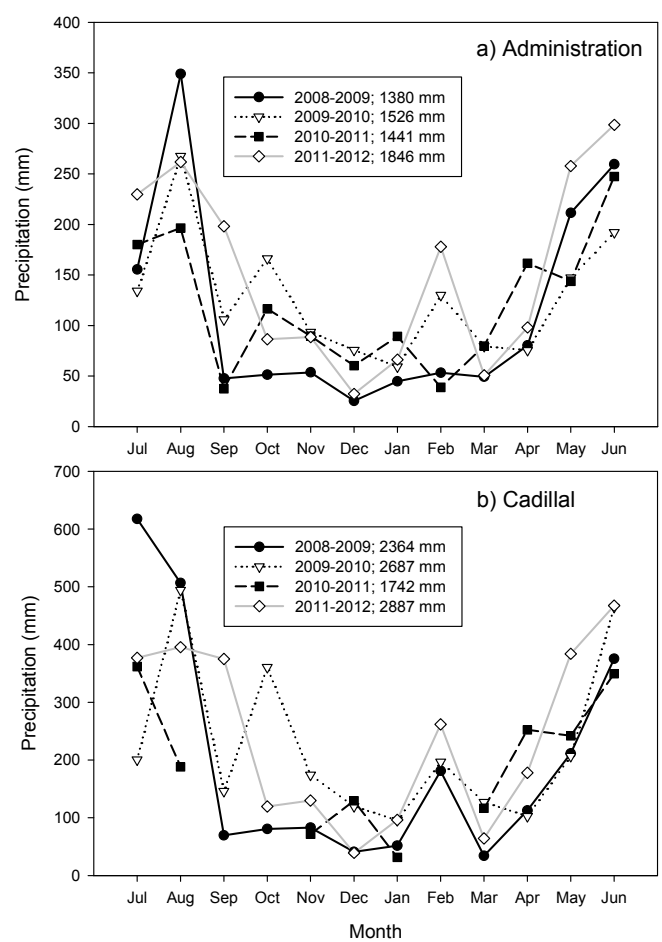

Figure 2. Precipitation trends for two meteorological stations located $16 \mathrm{~m}$ a.s.l. (Administration), and $113 \mathrm{~m}$ a.s.l. (Cadillal), over the four-year span of this study. The annual rainfall is indicated in millimeters over a 12-month period. In Cadillal, no data were available for September, October, and February in the period 2010-2011.

Precipitations were lower in spring and summer compared to autumn and winter. Although the years are not pluviometrically identical, the curves are intermingled and no clear trend from one year to the next can be perceived for equivalent months. In terms of percentage, annual rainfall presented a variation of 11 , -6 , and $28 \%$ from one year to the next, although the last value could be overestimated due to the missing data mentioned above.

The higher altitude at the Cadillal station was representative of the weather at RC10 and RC11. It rained 2364, 2687, 1742 and $2887 \mathrm{~mm}$ for the periods beginning in 2008, 2009, 2010 and 2011, respectively (Figure $2 \mathrm{~b}$ ). The precipitation between 2010 and 2011 was 
severely underestimated because the pluviometer was not functional for 4.5 months, including the months of September and October when a significant amount of rain falls. Once again, the curves are intermingled and in terms of percentage, there was a variation of 14 , -35 , and $66 \%$ from one year to the next. Considering the unreliable total precipitation of the period 20102011, we recalculated the variation of 2011-2012 as a percentage of the 2009-2010 precipitation, resulting in an increase of only $7 \%$.

The effect of rainfall on discharge (Q) was studied for each of the experimental periods. For example, the mean Q of RC1 from baseline to postharvest remained similar throughout this period (Table 2). The other watersheds began with a given $\mathrm{Q}$ that then decreased throughout the AF3 and AF15 periods, but all recovered markedly postharvest. RC6 increased its Q 1.5 times, while RC5, RC10 and RC11 increased their Qs 2.4 times.

The relationship between Q (extrapolated to the duration of each experimental period), rainfall and watershed area (rainfall/runoff coefficient, henceforth referred to as RR) showed a decrease in RC1. RC6 scarcely increased its RR. The other three watersheds showed less variation throughout most of the study, but all of them clearly increased their RRs between $\mathrm{AF} 15$ and postharvest.

Table 2. Variation in discharge (Q), precipitation (pp), and rainfall/runoff coefficient (RR) for the different periods analysed in this study, in a set of watersheds (RC1 to RC11). RC6 corresponds to the control (with no intervention). Periods were baseline, three (AF3) and 15 months (AF15) after fertilization, and postharvest of Eucalyptus plantations. Watersheds are arranged in increasing order of streamside native forest width.

\begin{tabular}{|c|c|c|c|c|}
\hline & Baseline & AF3 & AF15 & Postharvest \\
\hline $\begin{array}{l}\text { RC1 } \\
\text { Mean Q }\left(1 \mathrm{~s}^{-1}\right)\end{array}$ & 0.29 & 0.37 & 0.17 & 0.19 \\
\hline $\mathrm{pp}(\mathrm{mm})$ & 1864 & 310 & 1725 & 2321 \\
\hline $\mathrm{RR}(-)$ & 0.85 & 1.02 & 0.44 & 0.37 \\
\hline RC6 & & & & \\
\hline Mean Q $\left(1 \mathrm{~s}^{-1}\right)$ & 2.68 & 1.46 & 1.42 & 2.10 \\
\hline $\mathrm{pp}(\mathrm{mm})$ & 1842 & 309 & 1724 & 2398 \\
\hline $\mathrm{RR}(-)$ & 1.29 & 0.65 & 0.58 & 0.68 \\
\hline RC5 & & & & \\
\hline Mean Q $\left(1 \mathrm{~s}^{-1}\right)$ & 1.78 & 0.97 & 1.32 & 3.23 \\
\hline $\mathrm{pp}(\mathrm{mm})$ & 1844 & 235 & 1631 & 2275 \\
\hline $\mathrm{RR}(-)$ & 0.97 & 0.89 & 0.80 & 1.42 \\
\hline $\begin{array}{l}\text { RC11 } \\
\text { Mean Q }\left(1 \mathrm{~s}^{-1}\right)\end{array}$ & 3.41 & 0.91 & 2.51 & 6.12 \\
\hline $\mathrm{pp}(\mathrm{mm})$ & 2141 & 351 & 2214 & 3720 \\
\hline $\mathrm{RR}(-)$ & 0.77 & 0.47 & 0.87 & 1.40 \\
\hline $\begin{array}{l}\text { RC10 } \\
\text { Mean Q }\left(1 \mathrm{~s}^{-1}\right)\end{array}$ & 2.66 & 1.20 & 1.24 & 2.96 \\
\hline $\mathrm{pp}(\mathrm{mm})$ & 1309 & 611 & 2518 & 3720 \\
\hline $\mathrm{RR}(-)$ & 0.75 & 0.41 & 0.46 & 0.84 \\
\hline
\end{tabular}




\subsection{Response to fertilization}

The time series of all nutrients studied (Figures $3 a$ to 3f) showed that in all cases there were export fluctuations that were season related: there were higher exports in the winter and at the beginning of spring, and lower exports throughout the remaining seasons. However, superposed to this pattern there were also variations within a season, driven by specific rain events that can occur at any time of year.

$\mathrm{NO}_{3}^{-}$-N showed relatively low exports $\left(<<1 \mathrm{mg} \mathrm{m}^{-2}\right.$ day $\left.^{-1}\right)$ in the pre-fertilization period, with the excep- tion of July/August 2009 when some minor peaks were observed (Figure 3a). Variations were similar among watersheds, but RC6 (the control) showed slightly higher values than the other catchments. After fertilization, some small increases in export were observed (October/November 2009) due to rain events during those days. Exports increased 1.1-3.6 times (the highest value corresponds to RC10) compared with the baseline average for each catchment. However, over the long-term these variations were not significant at the three (AF3) nor the 15 month (AF15) evaluations (Table 3 ).

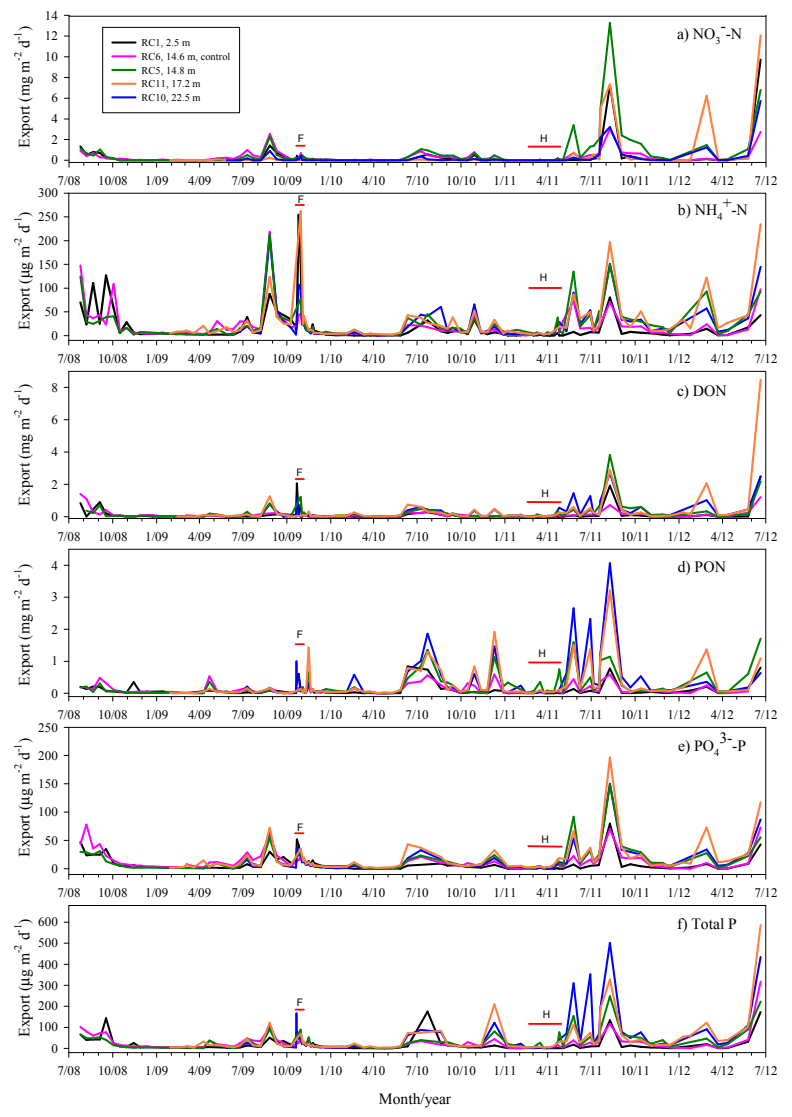

Figure 3. Temporal series of nutrient exports to streams in watersheds of the Reserva Costera Valdiviana, with varying streamside native forest widths (indicated in meters, $\mathrm{m}$ ). Red bars indicate the time of fertilization (F), while $\mathrm{H}$ is the lapse of clear-cutting of Eucalyptus plantations. DON = dissolved organic nitrogen; PON = particulate organic nitrogen. For better clarity, the symbols for each curve were omitted. 
Table 3. Statistical comparisons of stream nutrient exports $\left(\mu \mathrm{g} \mathrm{m}^{-2} \mathrm{day}^{-1}\right)$ for several watersheds located in the Reserva Costera Valdiviana (RC1 to RC11). RC6 corresponds to the control watershed (with no intervention). Periods are baseline, three (AF3) and 15 months (AF15) after fertilization, and postharvest of Eucalyptus plantations. Watersheds are arranged in increasing order of streamside native forest width.

\begin{tabular}{|c|c|c|c|c|c|c|c|c|}
\hline & \multicolumn{2}{|c|}{ Baseline } & \multicolumn{2}{|c|}{ AF3 } & \multicolumn{2}{|c|}{ AF15 } & \multicolumn{2}{|c|}{ Postharvest } \\
\hline & Mean & $\mathrm{SE}^{(\mathrm{a})}$ & Mean & SE & Mean & SE & Mean & SE \\
\hline \multicolumn{9}{|l|}{$\mathrm{NO}_{3}{ }^{-}-\mathrm{N}$} \\
\hline $\begin{array}{l}\text { RC1 } \\
\text { RC6 } \\
\text { RC5 } \\
\text { RC11 } \\
\text { RC10 }\end{array}$ & $\begin{array}{l}247.3 \\
323.3 \\
342.7^{\mathrm{A}} \\
41.2^{\mathrm{AB}} \\
122.6^{\mathrm{AB}}\end{array}$ & $\begin{array}{l}84.5 \\
93.2 \\
99.4 \\
12.1 \\
86.8\end{array}$ & $\begin{array}{l}152.9 \\
187.6 \\
138.3^{\mathrm{A}} \\
23.6^{\mathrm{AB}} \\
64.5^{\mathrm{AB}}\end{array}$ & $\begin{array}{l}35.2 \\
41.3 \\
36.0 \\
3.0 \\
31.8\end{array}$ & $\begin{array}{l}111.5 \\
192.4 \\
206.3^{\mathrm{A}} \\
27.1^{\mathrm{A}} \\
50.7^{\mathrm{A}}\end{array}$ & $\begin{array}{l}25.9 \\
34.5 \\
45.6 \\
3.0 \\
16.3\end{array}$ & $\begin{array}{l}839.7 \\
422.5 \\
2119.3^{\mathrm{B}} \\
1253.6^{\mathrm{B}} \\
666.6^{\mathrm{B}}\end{array}$ & $\begin{array}{l}531.4 \\
132.2 \\
707.4 \\
576.6 \\
296.9\end{array}$ \\
\hline \multicolumn{9}{|l|}{$\mathrm{NH}_{4}{ }^{+}-\mathrm{N}$} \\
\hline $\begin{array}{l}\text { RC1 } \\
\text { RC6 } \\
\text { RC5 } \\
\text { RC11 } \\
\text { RC10 }\end{array}$ & $\begin{array}{l}29.2^{\mathrm{A}} \\
30.6 \\
32.0^{\mathrm{AB}} \\
32.8^{\mathrm{AB}} \\
35.1\end{array}$ & $\begin{array}{l}7.2 \\
8.7 \\
8.9 \\
13.4 \\
19.6\end{array}$ & $\begin{array}{l}43.5^{\mathrm{A}} \\
15.8 \\
13.0^{\mathrm{AB}} \\
11.8^{\mathrm{A}} \\
25.2\end{array}$ & $\begin{array}{l}19.3 \\
3.6 \\
3.6 \\
3.6 \\
9.1\end{array}$ & $\begin{array}{l}20.6^{\mathrm{AB}} \\
11.5 \\
13.2^{\mathrm{A}} \\
14.4^{\mathrm{A}} \\
18.9\end{array}$ & $\begin{array}{l}8.0 \\
1.9 \\
2.1 \\
2.5 \\
4.4\end{array}$ & $\begin{array}{l}9.6^{\mathrm{B}} \\
17.3^{4} \\
43.8^{\mathrm{B}} \\
41.5^{\mathrm{B}} \\
36.5\end{array}$ & $\begin{array}{l}3.9 \\
4.2 \\
9.6 \\
11.2 \\
8.7\end{array}$ \\
\hline \multicolumn{9}{|l|}{$\mathbf{D O N}^{(b)}$} \\
\hline $\begin{array}{l}\text { RC1 } \\
\text { RC6 } \\
\text { RC5 } \\
\text { RC11 } \\
\text { RC10 }\end{array}$ & $\begin{array}{l}121.4 \\
179.8 \\
206.7^{\mathrm{AB}} \\
137.7^{\mathrm{A}} \\
142.2^{\mathrm{AB}}\end{array}$ & $\begin{array}{l}52.6 \\
63.2 \\
65.1 \\
71.4 \\
76.1 \\
\end{array}$ & $\begin{array}{l}249.4 \\
47.9 \\
108.3^{\mathrm{AB}} \\
74.6^{\mathrm{AB}} \\
151.8^{\mathrm{AB}}\end{array}$ & $\begin{array}{l}148.5 \\
15.0 \\
28.1 \\
26.4 \\
78.3\end{array}$ & $\begin{array}{l}126.2 \\
67.8 \\
112.9^{\mathrm{A}} \\
146.3^{\mathrm{AB}} \\
159.8^{\mathrm{A}}\end{array}$ & $\begin{array}{l}61.3 \\
16.0 \\
22.2 \\
32.4 \\
38.3\end{array}$ & $\begin{array}{l}229.4 \\
143.6 \\
566.1^{\mathrm{B}} \\
681.6^{\mathrm{B}} \\
582.5^{\mathrm{B}}\end{array}$ & $\begin{array}{l}137.3 \\
46.6 \\
206.3 \\
342.4 \\
160.4\end{array}$ \\
\hline \multicolumn{9}{|l|}{$\mathbf{P O N}^{(c)}$} \\
\hline $\begin{array}{l}\text { RC1 } \\
\text { RC6 } \\
\text { RC5 } \\
\text { RC11 } \\
\text { RC10 }\end{array}$ & $\begin{array}{l}74.3 \\
90.0 \\
74.0^{\mathrm{A}} \\
47.3^{\mathrm{A}} \\
39.0^{\mathrm{A}}\end{array}$ & $\begin{array}{l}16.6 \\
24.4 \\
18.2 \\
11.7 \\
20.3 \\
\end{array}$ & $\begin{array}{l}138.3 \\
72.4 \\
127.2^{\mathrm{AB}} \\
184.3^{\mathrm{AB}} \\
194.2^{\mathrm{AB}}\end{array}$ & $\begin{array}{l}46.1 \\
13.9 \\
48.9 \\
124.5 \\
74.3 \\
\end{array}$ & $\begin{array}{l}117.6 \\
113.4 \\
217.2^{\mathrm{AB}} \\
288.8^{\mathrm{B}} \\
286.3^{\mathrm{B}}\end{array}$ & $\begin{array}{l}34.2 \\
23.8 \\
54.1 \\
82.1 \\
73.4\end{array}$ & $\begin{array}{l}108.2 \\
113.1 \\
485.3^{\mathrm{B}} \\
440.0^{\mathrm{B}} \\
612.2^{\mathrm{B}}\end{array}$ & $\begin{array}{l}48.2 \\
31.6 \\
133.4 \\
136.1 \\
205.5\end{array}$ \\
\hline \multicolumn{9}{|l|}{$\mathrm{PO}_{4}{ }^{3-}-\mathrm{P}$} \\
\hline $\begin{array}{l}\text { RC1 } \\
\text { RC6 } \\
\text { RC5 } \\
\text { RC11 } \\
\text { RC10 }\end{array}$ & $\begin{array}{l}11.7^{\mathrm{AB}} \\
16.8 \\
13.0^{\mathrm{AB}} \\
12.3^{\mathrm{AB}} \\
12.3^{\mathrm{A}}\end{array}$ & $\begin{array}{l}2.4 \\
3.3 \\
2.6 \\
3.7 \\
6.4\end{array}$ & $\begin{array}{l}15.6^{\mathrm{A}} \\
8.8^{\mathrm{AB}} \\
9.0^{\mathrm{AB}} \\
7.5^{\mathrm{AB}} \\
12.0\end{array}$ & $\begin{array}{l}3.9 \\
1.6 \\
1.5 \\
1.5 \\
2.9\end{array}$ & $\begin{array}{l}8.4^{\mathrm{AB}} \\
7.0^{\mathrm{A}} \\
8.1^{\mathrm{A}} \\
10.1^{\mathrm{A}} \\
9.6\end{array}$ & $\begin{array}{l}2.1 \\
1.1 \\
1.2 \\
2.1 \\
1.8\end{array}$ & $\begin{array}{l}8.3^{\mathrm{B}} \\
11.8^{3} \\
30.5^{\mathrm{B}} \\
29.4^{\mathrm{B}} \\
26.5^{\circ}\end{array}$ & $\begin{array}{l}3.9 \\
3.2 \\
7.5 \\
8.1 \\
7.0\end{array}$ \\
\hline \multicolumn{9}{|l|}{ Total P } \\
\hline $\begin{array}{l}\mathrm{RC} 1 \\
\mathrm{RC6} \\
\mathrm{RC5} \\
\mathrm{RC} 11 \\
\mathrm{RC} 10\end{array}$ & $\begin{array}{l}23.2^{\mathrm{A}} \\
29.2^{\mathrm{A}} \\
26.8^{\mathrm{A}} \\
22.4^{\mathrm{AB}} \\
21.8^{\mathrm{AB}}\end{array}$ & $\begin{array}{l}5.9 \\
5.3 \\
5.1 \\
6.3 \\
10.7\end{array}$ & $\begin{array}{l}26.7^{\mathrm{A}} \\
16.6 \\
17.7^{\mathrm{AB}} \\
12.7^{\mathrm{AB}} \\
32.5^{\mathrm{AB}}\end{array}$ & $\begin{array}{l}6.1 \\
3.4 \\
4.0 \\
2.5 \\
11.5\end{array}$ & $\begin{array}{l}20.3^{\mathrm{AB}} \\
13.8^{\mathrm{A}} \\
17.4^{\mathrm{A}} \\
25.0^{\mathrm{A}} \\
28.3^{\mathrm{A}}\end{array}$ & $\begin{array}{l}6.2 \\
2.3 \\
3.1 \\
7.9 \\
7.1\end{array}$ & $\begin{array}{l}20.0^{\mathrm{B}} \\
27.2^{\mathrm{B}} \\
69.3^{\mathrm{B}} \\
75.6^{\mathrm{B}} \\
108.7^{\mathrm{B}}\end{array}$ & $\begin{array}{l}9.3 \\
10.3 \\
17.2 \\
24.7 \\
30.6\end{array}$ \\
\hline
\end{tabular}

(a) $\mathrm{SE}=$ standard error of the average.

(b) $\mathrm{DON}=$ dissolved organic nitrogen.

(c) $\mathrm{PON}=$ particulate organic nitrogen.

Different superscript capital letters indicate differences of $p<0.05$ (HSD or mean rank tests, following ANOVAs or Kruskal-Wallis tests, respectively), only for comparisons within a watershed across different treatments. When no differences were detected, the superscripts were omitted. 
$\mathrm{NH}_{4}{ }^{+} \mathrm{N}$ exports were very low as compared to $\mathrm{NO}_{3}{ }_{3}^{-}$ $-\mathrm{N}$, but showed important variations before and after fertilization (Figure 3b). Immediately after fertilization, the export values detected in $\mathrm{RC} 1$ increased by 9 times, while the values found in the other catchments increased by 1.3-3 times (RC11's peak in Figure $3 b$ under "F" represents pre-fertilization). Despite a general declining trend after the fertilization, over the longer term this was not significant in any of the catchments (Table 3).

DON responded to fertilization (Figure 3c) in RC1, increasing by 17 times and in $\mathrm{RC} 10$ by eight times. The other catchments showed scarce variations, with increases of 1.3-2.3 times. Over the long term (AF3, AF15), the response to fertilization was not significant (Table 3 ).

All catchments had similar dynamics in relation to PON exports during the pre-fertilization period (Figure $3 \mathrm{~d}$ ). Immediately after the addition of nutrients, the exports peaked: RC1 increased 8 times, RC6 twice, RC10 25 times, RC5 9 times and, RC11 30 times. Over the long term, no significant increases after fertilization were observed, except in RC10 and $\mathrm{RC} 11$, which varied greatly between the baseline and AF15 (Table 3).

$\mathrm{PO}_{4}^{3-}-\mathrm{P}$ exports in $\mathrm{RC} 1$ increased four times immediately after fertilization, while the other catchments responded less to fertilization (1.4-3 times) (Figure 3e). This effect did not sustain itself over the longer term in any of the catchments (Table 3).

Total $\mathrm{P}$ (which includes $\mathrm{PO}_{4}{ }^{3-}-\mathrm{P}$ ) increased eight times in RC10 immediately after fertilization, while the other watersheds fluctuated among increases of 1.43.3 times (Figure $3 \mathrm{f}$ ). No differences regarding total $\mathrm{P}$ were detected over the longer term (Table 3).

\subsection{Response to harvest}

After harvest, there were large increases in nitrate exports surpassing $1 \mathrm{mg} \mathrm{m}^{-2}$ day $^{-1}$, a trend that was significant in all of the studied watersheds except RC1 and RC6, especially when comparing AF15 with the postharvest period. RC6 doubled its exports, while the other catchments rose between $8(\mathrm{RC} 1)$ and 46 times (RC11) compared to AF15 (Table 3, Figure 3a).

After harvest, $\mathrm{RC} 1$ had a lower $\mathrm{NH}_{4}^{+}$-N export than at the baseline, but that export level then remained the same than 15 months after fertilization. Neither RC6 nor RC10 responded to the harvest, while both RC5 and RC11 significantly increased their $\mathrm{NH}_{4}{ }^{+} \mathrm{N}$ exports, by three times (Table 3 ). This is clearly seen in Figure $3 \mathrm{~b}$ (green and orange curves), while preharvest all of the evaluated watersheds were very similar in terms of their ammonium losses.

After harvest, DON increased significantly in RC5 (five times) and RC10 (3.6 times) (Table 3). Although RC11 presented no differences when comparing the postharvest and AF15 periods, its DON levels did increase by a factor of five when postharvest values were compared to those at the baseline. Thus, RC5 and RC10 showed a clear effect related to the clearcutting, contrary to the other catchments (RC1, RC6) (Figure 3c).

PON exports in RC1 and RC6 showed no response to the harvest, while the other catchments showed a clear increase compared to the baseline PON exports, but not compared to the previous period (AF15) (Figure 3d, Table 3).

$\mathrm{PO}_{4}^{3-}$-P exports in $\mathrm{RC} 1, \mathrm{RC} 6$, and $\mathrm{RC} 10$ did not respond to the harvest, while the remaining catchments significantly increased these exports, by 2.9-3.8 times (Figure 3e, Table 3). After the harvest, $\mathrm{RC} 1$ exported less $\mathrm{PO}_{4}^{3-}-\mathrm{P}$ than $\mathrm{AF} 3$, but these $\mathrm{PO}_{4}^{3-}-\mathrm{P}$ exports were not significantly different from AF15. Finally, the total P exports in RC6 showed no significant response postharvest. On the other hand, RC1 exported less total $\mathrm{P}$ after the harvest than at the baseline and AF3, but $\mathrm{RC} 1$ 's lower total $\mathrm{P}$ exports postharvest were the same as those recorded AF15 (Figure 3f, Table 3). The three 
other catchments significantly increased their export by 3-4 times.

After harvest, with the exception of nitrate, all of the studied catchments had a similar response magnitude regardless of the streamside native forest width.

\subsection{Sediment rough exports}

Temporal series showed large fluctuations in sediment exports both in the preharvest period, as well as after the clear-cut period (Figure 4). POM-gravel exports were highest in RC10 and RC11 throughout the study (Figure 4a). With the exception of $\mathrm{RC} 1$, this fraction increased in all evaluated watersheds after the harvest. The ratio of change was greatest in RC6 (14 times), while in the other catchments it increased 4-5 times (Table 4). Silicicoclastic gravel presented a similar pattern (Figure 4b).
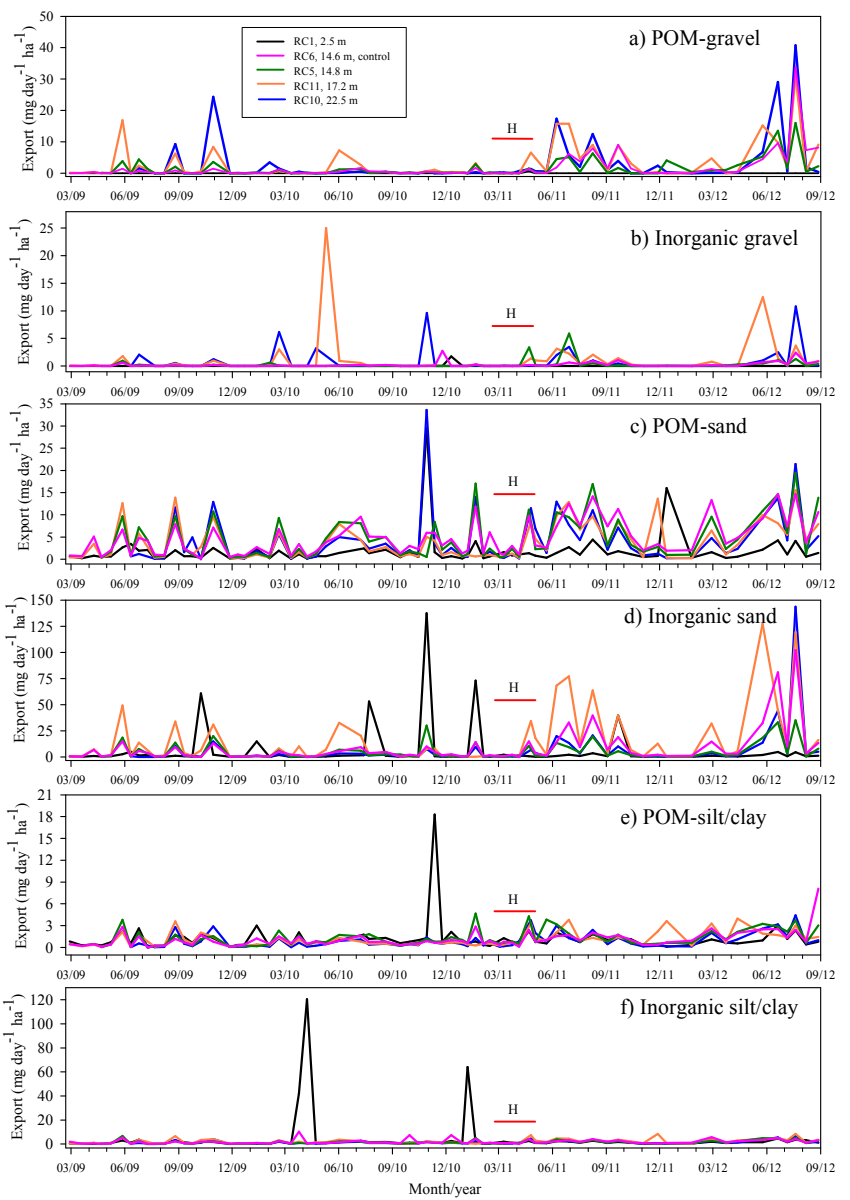

Figure 4. Temporal series of rough sediment exports to streams in watersheds of the Reserva Costera Valdiviana, with varying streamside native forest widths (indicated in meters, $\mathrm{m}$ ). Red bars $(\mathrm{H})$ indicate the lapse of clearcutting of Eucalyptus plantations. For better clarity, the symbols and standard errors for each curve were omitted. $\mathrm{POM}=$ particulate organic matter of a specific granulometry. 
Table 4. Statistical comparisons of stream cumulative sediments collected in several watersheds located in the Reserva Costera Valdiviana, before and after the clear-cutting of Eucalyptus plantations. RC6 corresponds to the control watershed (without harvest). Italic values represent significant effects with a $p<0.05$. Watersheds are arranged in increasing order of streamside native forest width.

\begin{tabular}{|c|c|c|c|c|c|c|c|}
\hline \multirow{2}{*}{$\begin{array}{l}\text { Grain class/ } \\
\text { Watershed }\end{array}$} & \multicolumn{2}{|c|}{ Before harvest } & \multicolumn{2}{|c|}{ After harvest } & \multirow[t]{2}{*}{$\mathrm{t}_{\mathrm{s}}^{(\mathrm{b})}$} & \multirow[t]{2}{*}{$p^{(\mathrm{c})}$} & \multirow{2}{*}{$\begin{array}{l}\text { Ratio } \\
\text { of change } \\
\text { (after:before } \\
\text { harvest) }\end{array}$} \\
\hline & $\begin{array}{c}\text { Mean } \\
\left(\mathrm{mg} \mathrm{day}^{-1}\right. \\
\left.\mathrm{ha}^{-1}\right)\end{array}$ & $\begin{array}{c}\mathrm{SE}^{(\mathrm{a})} \\
\left(\mathrm{mg} \mathrm{day}^{-1}\right. \\
\left.\mathrm{ha}^{-1}\right)\end{array}$ & $\begin{array}{c}\text { Mean } \\
\left(\mathrm{mg} \mathrm{day}^{-1}\right. \\
\left.\mathrm{ha}^{-1}\right)\end{array}$ & $\begin{array}{c}\mathrm{SE} \\
\left(\mathrm{mg} \mathrm{day}^{-1}\right. \\
\left.\mathrm{ha}^{-1}\right)\end{array}$ & & & \\
\hline \multicolumn{8}{|c|}{ POM $^{(\mathrm{d})}$-gravel } \\
\hline $\mathrm{RC} 1$ & 0.02 & 0.01 & 0.02 & 0.02 & 0.404 & 0.686 & 1.0 \\
\hline RC6 & 0.28 & 0.07 & 3.77 & 1.31 & -3.258 & 0.001 & 13.5 \\
\hline $\mathrm{RC} 5$ & 0.55 & 0.17 & 2.92 & 0.88 & -3.761 & $<0.001$ & 5.3 \\
\hline $\mathrm{RC} 11$ & 1.25 & 0.49 & 5.47 & 1.45 & -3.037 & 0.002 & 4.4 \\
\hline $\mathrm{RC} 10$ & 1.22 & 0.73 & 4.74 & 1.87 & -3.436 & $<0.001$ & 3.9 \\
\hline \multicolumn{8}{|l|}{$\begin{array}{l}\text { Inorganic } \\
\text { gravel }\end{array}$} \\
\hline $\mathrm{RC} 1$ & 0.04 & 0.04 & 0.00 & 0.00 & 0.404 & 0.686 & 0.0 \\
\hline RC6 & 0.11 & 0.06 & 0.35 & 0.10 & -2.861 & 0.004 & 3.2 \\
\hline $\mathrm{RC} 5$ & 0.06 & 0.03 & 0.62 & 0.28 & -3.931 & $<0.001$ & 9.7 \\
\hline $\mathrm{RC} 11$ & 0.81 & 0.60 & 1.25 & 0.49 & -2.628 & 0.009 & 1.6 \\
\hline $\mathrm{RC} 10$ & 0.66 & 0.33 & 0.82 & 0.42 & -2.643 & 0.008 & 1.2 \\
\hline \multicolumn{8}{|l|}{ POM-sand } \\
\hline $\mathrm{RC} 1$ & 1.73 & 0.65 & 2.13 & 0.65 & -1.726 & 0.084 & 1.2 \\
\hline RC6 & 3.34 & 0.42 & 6.64 & 0.89 & -3.239 & 0.001 & 2.0 \\
\hline RC5 & 3.22 & 0.57 & 7.14 & 1.15 & -3.618 & $<0.001$ & 2.2 \\
\hline $\mathrm{RC} 11$ & 2.54 & 0.50 & 5.76 & 0.88 & -3.004 & 0.003 & 2.3 \\
\hline $\mathrm{RC} 10$ & 3.49 & 1.04 & 5.08 & 1.02 & -1.792 & 0.073 & 1.5 \\
\hline \multicolumn{8}{|l|}{$\begin{array}{l}\text { Inorganic } \\
\text { sand }\end{array}$} \\
\hline $\mathrm{RC} 1$ & 8.35 & 3.75 & 2.92 & 1.62 & -0.920 & 0.358 & 0.3 \\
\hline RC6 & 3.32 & 0.60 & 15.52 & 4.73 & -3.215 & 0.001 & 4.7 \\
\hline RC5 & 3.48 & 0.96 & 7.70 & 2.10 & -2.892 & 0.004 & 2.2 \\
\hline $\mathrm{RC} 11$ & 6.27 & 1.71 & 26.90 & 7.15 & -2.739 & 0.006 & 4.3 \\
\hline $\mathrm{RC} 10$ & 1.97 & 0.56 & 11.24 & 5.42 & -2.514 & 0.012 & 5.7 \\
\hline \multicolumn{8}{|c|}{ POM-silt/clay } \\
\hline $\mathrm{RC} 1$ & 1.32 & 0.40 & 1.08 & 0.15 & -0.731 & 0.465 & 0.8 \\
\hline RC6 & 0.77 & 0.10 & 1.56 & 0.29 & -3.264 & 0.001 & 2.0 \\
\hline $\mathrm{RC} 5$ & 0.94 & 0.14 & 1.88 & 0.26 & -3.262 & 0.001 & 2.0 \\
\hline $\mathrm{RC} 11$ & 0.71 & 0.11 & 1.66 & 0.23 & -3.925 & $<0.001$ & 2.3 \\
\hline $\mathrm{RC} 10$ & 0.59 & 0.11 & 1.31 & 0.23 & -2.778 & 0.005 & 2.2 \\
\hline \multicolumn{8}{|l|}{$\begin{array}{l}\text { Inorganic } \\
\text { silt/clay }\end{array}$} \\
\hline $\mathrm{RC} 1$ & 6.08 & 3.08 & 1.64 & 0.23 & -1.499 & 0.134 & 0.3 \\
\hline RC6 & 1.64 & 0.33 & 2.15 & 0.29 & -2.588 & 0.010 & 1.3 \\
\hline RC5 & 1.09 & 0.20 & 2.17 & 0.33 & -3.262 & 0.001 & 2.0 \\
\hline $\mathrm{RC} 11$ & 1.41 & 0.23 & 3.09 & 0.46 & -3.332 & $<0.001$ & 2.2 \\
\hline $\mathrm{RC} 10$ & 0.77 & 0.15 & 1.92 & 0.35 & -3.069 & 0.002 & 2.5 \\
\hline
\end{tabular}

(a) $\mathrm{SE}=$ standard error of the average.

(b) $\mathrm{t}_{\mathrm{s}}=$ Student's $\mathrm{t}$ statistics calculated for a Mann-Whitney test.

(c) $p=$ probability for a two-tailed test.

(d) $\mathrm{POM}=$ particulate organic matter of a specific granulometry. 
POM-sand exports were quite similar among watersheds and relatively parallel over time (Figure 4c). Exports almost doubled after the harvest (Table 4). Inorganic sand showed similar dynamics to the organic fraction (Figure 4d), and significant differences were observed in all of the watersheds after the clearcutting operation (increases of 2.2-5.7 times), except for RC1 (Table 4). Furthermore, this was the most abundant of all the grain size classes detected.

Mud had similar values for all evaluated catchments, and only sporadically did RC1 export more sediment (Figures 4e, f). When significant changes were detected before/after harvest, the ratio of change was 1.3 to 2.5 times more (Table 4$)$.

In several cases (Figures 4c, d, e, f), RC1 showed very large exports, but this was not enough to produce a significant difference in response to clearcutting, compared to the other watersheds. Moreover, in most cases no consistent difference was detected in relation to the magnitude of variation in experimental versus control catchments. No relationship regarding the SNFW was detected either.

\section{Discussion}

\subsection{Element exports}

Usually, these kinds of studies employ the concentration and/or export as response variables. However, similar stream concentrations before and after an ecosystem disturbance do not necessarily indicate a lack of response, unless precipitation/discharge have not changed from the baseline to the treatment. More frequently, changes in discharge may imply that the watershed needs to lose more or less elements to maintain the original nutrient concentration. Therefore, we preferred to use exports in our analyses, given that the discharge factor considers the influence of land cover, land cover change, and rainfall. For the same reason, we assessed the possibility that export variations over time can result from varying rainfall/discharge patterns rather than land cover changes. In our study, annual rainfall showed some increases from one year to the next, but they were generally weak to moderate (7$30 \%$ increase), making it difficult to explain all of the fluctuations in exports, before/after the experimental treatments, in terms of precipitation only. In general, discharge also clearly increased after the harvest. The use of the rainfall/runoff coefficient allowed discharge to be expressed per unit of precipitation, concluding that after harvest there was a drastic increase in $\mathrm{Q}$, which was not exclusively explained by rainfall, but also by land cover change. This pattern could be associated with the clearing of the evapotranspirating plantations and the elimination of rain interception by their canopies, as demonstrated by several studies (e.g., Iroumé et al., 2006; Winkler et al., 2017). Even some RRs were above the theoretical maximum value of 1.0. Frêne (2010) found this pattern for specific months over the summer in the Bío Bío Region in Chile. The explanation may have to deal with i) cloud/ fog water contributing to the precipitation input of the catchments, an input that is frequent in the study site, but could not be quantified with our conventional rain gauges (see also Bruijnzeel, 2001); ii) our RRs were not calculated for annual periods, but for 3 or 14-16 month periods. Therefore, when evaluating long periods with streamflow, but with little rain, it is perfectly possible to surpass the value of 1.0.

Moreover, to further assure that our study reflected the effect of disturbances, rather than the effect of precipitations, we compared the behaviour of experimental watersheds with a control located in the same climatic zone. The analysis confirmed that the control watershed increased its $\mathrm{Q}$ and $\mathrm{RR}$ much less than the harvested catchments. In other words, the net nutrient losses were caused by the disturbances applied to the experimental catchments. 


\subsection{Response to fertilization}

In general, all nutrients analysed showed similar dynamics in a temporal dimension, driven by seasonal precipitation trends: higher losses during rainy seasons and lower losses during dry seasons. The pattern replicated itself on shorter timescales (days, weeks), when rain events stimulated nutrient releases and discharges, which together explain the higher exports. Given the prevailing occurrence of precipitation in the studied region (Figure 2), a sudden release of nutrients can be produced in any season when rain influences streamflow by surface, subsurface and/or groundwater flows. In fact, Little et al. (2015) found that precipitation over the last 15 days is a good predictor stream of nutrient concentrations observed on the day of sampling.

In the short-term, some catchments and nutrients responded immediately and clearly to the fertilization period (e.g., $\mathrm{NH}_{4}^{+}-\mathrm{N}$, total $\mathrm{P}$ ). The peak occurred in $\mathrm{RC} 1$ and $\mathrm{RC} 10$ before $\mathrm{RC} 5$ and $\mathrm{RC} 11$. The most likely explanation is the order in which the catchments were fertilized. $\mathrm{RC} 1$ and $\mathrm{RC} 10$ were treated on October $19^{\text {th }}$ and $20^{\text {th }}$, on rainy days that were followed by abundant precipitation $(86.4 \mathrm{~mm}$ between October 19 and 23), while RC5 and RC11 were fertilized at the start of November, when precipitation levels reached only $56.4 \mathrm{~mm}$ (between November 2 and 5). This lower rainfall may also explain why some nutrients $\left(\mathrm{NH}_{4}^{+}\right.$-N, total P) showed lower increases in RC5 and RC11 when compared to RC1 and RC10. Thus, nutrient release differences seem to be associated with fertilizer movement (calcareous ammonium nitrate and triple superphosphate) on the rainy days that followed or accompanied the fertilization processes, in accordance with the observations made by Beltran et al. (2010). However, the rainfall pattern does not explain the higher PON losses that were observed during the same periods. Since all applied fertilizers were inor- ganic, this result suggests that inorganic $\mathrm{N}$ was taken up by soil or aquatic microorganisms between the day of fertilization and the day of peak export in the stream (a lapse of 2-14 days), resulting in increased PON exports.

A concluding evaluation about the source of $\mathrm{N}$ and $\mathrm{P}$ in streams would require further knowledge regarding the proportion of nutrients attributable to fertilizers, versus those in the soil pool, with stable isotopes for instance (Bateman et al., 2005). Notwithstanding, a simple calculation of the losses from our export series during the first month after fertilization showed that $\mathrm{N}$ was released at rates of some hundreds of grams, while $\mathrm{P}$ was released at rates of some dozens of grams (data not shown). These values are very low compared to the 63 and $45 \mathrm{~kg} \mathrm{ha}^{-1}$ applied as $\mathrm{N}$ and P, respectively. Thus, our results suggest that only a small proportion of the fertilizer was lost during the days or weeks following the application. In a broader evaluation, considering a long-term time scale (3-15 months after fertilization), no significant effects were detected for most watersheds and nutrients analysed. The exceptions were $\mathrm{RC} 10$ and $\mathrm{RC} 11$, which increased their PON exports when AF15 was compared with the baseline. As previously mentioned, this may be an indirect effect of fertilization. Thus, in the long-term the fertilization treatments applied here showed no major, direct effect in any of the analysed watersheds in relation to the evaluated nutrients. This differs from other studies (Beltran et al., 2010 and references therein), which have shown that fertilizers have a significant effect on stream water quality.

Our results, obtained over the medium and long-term, could be due to the rate of fertilizer applied, which was adequate for Eucalyptus nutrition. Moreover, the plantation understory, although scarce, included blackberry (Rubus constrictus) and other plants. The low nutrient content of these soils can also be an important sink for nitrogen, phosphorus and other ele- 
ments. In fact, several studies have reported that the atmospheric inputs of nutrients, especially inorganic nitrogen, are very low (Hedin et al., 1995). This is the case with the non-symbiotic $\mathrm{N}$ fixation (Pérez et al., 2003) and $\mathrm{N}$ mineralization in pristine soils (Pérez et al., 1998). More recently, other processes have been reported to immobilize $\mathrm{N}$ in soils: microbial absorption and nitrate immobilization in soluble organic nitrogen fractions of the soil (Huygens et al., 2008). Thus, plants and microorganisms readily use the low $\mathrm{N}$ soil levels, with scarce inorganic losses to streams over the long-term.

Regarding the Olsen P tests, their values were also very low in the studied soils. This can be a consequence of the high $\mathrm{P}$ adsorption due to the aluminum and hydrous oxide composition in amorphous clays (Alfaro et al., 2008). The low soil pH accentuates this pattern because of the aluminum solubilization in acidic soils. In fact, Meyer (2016) found evidence of the dominance of such clays (allophan and imogolite) in the lower horizons of soils located $3 \mathrm{~km}$ from our study site.

\subsection{Response to harvest}

Most nutrient exports were clearly higher in the harvested watersheds, especially when comparing AF15 with postharvest. Since RC6 showed no significant variations during the period when other watersheds were being cut, it represents an adequate control to evaluate the effect the harvest had on the experimental catchments. RC1 (an intervened watershed with the lowest SNFW) behaved atypically because it never responded to harvest. This is probably a consequence of the low $\mathrm{RC} 1$ area ( $0.85 \mathrm{ha}$ ) compared to the other catchments that were up to six times larger. This means that the area of denuded soil that could contribute to exports with nutrients and sediments was very small compared to the other catchments. In other words, the change of vegetation in RC1 had no significant effect on stream properties most likely due to an issue of spatial scale. The postharvest decrease in $\mathrm{NH}_{4}{ }^{+}-\mathrm{N}$ and total $\mathrm{P}$ exports in $\mathrm{RC} 1$, compared to these exports at the start of the study, could be due to the decreasing discharge (Table 2).

Postharvest PON exports were no different than those observed AF15 in all of the harvested catchments that responded to clearcutting. Nonetheless, postharvest PON exports in these watersheds were higher than those at the baseline, suggesting that the loss observed was a pattern present prior to harvest.

Other studies summarized in Baillie and Neary (2015) showed that stream nutrient concentrations increased after clear-cut, especially nitrate. Total phosphorus showed little response and, in other cases, harvesting had no effect on the streams associated with good management practices.

\subsection{Sediment rough exports}

Sediments also showed large temporal fluctuations, driven by rain events. Most watersheds showed a significant increase in their accumulation of sediments after the plantation harvest (even the control), for all of the grain sizes evaluated. This means that the variations of sediment exports are also a consequence of the internal dynamics of the catchments. The only exception was the smallest watershed, RC1, which showed no significant variations for any of the evaluated fractions. Interestingly, $\mathrm{RC} 1$ showed some large fluctuations on specific dates (both before and after harvest), which suggests that it has the potential to release sediments.

Since, in general, no differences were observed in the responses of the experimental catchments versus the control, we conclude that harvesting produced no major effect on stream sediments. Our results differ from those obtained by Huber 
(2009) and Frêne (2010) who found significant increases in sediment exports in harvested stands dominated by Pinus radiata compared with control catchments. These authors explained their findings based on the poor design and maintenance of forestry roads, absent riparian strips or strips with a shrubby composition, in addition to harvesting during winter. Conversely, our results can be explained by improved management practices during forestry operations, namely: a small harvest area within each watershed, activities spaced over time (up to two months in some cases), harvesting during the summer and the beginning of autumn, no harvesting on rainy days, reduced use of the harvester machine, planned logging tracks, and planned log yards.

Moreover, SNFW did not play any role in discriminating catchments regarding their sediment exports, and it is clear that the higher losses occurred in the seasons and periods with high rainfall. Nutrient losses can occur overland, at a subsurface level or as part of the groundwater flow. These cannot be discriminated by using our experimental protocol, but the absence of differences in the sediment response among watersheds suggests that the extra release of nutrients in harvested sites was produced by subterranean flows.

\subsection{Role of riparian vegetation}

There is a substantial amount of literature dealing with the buffering effect of riparian vegetation strips (reviewed by Lowrance, 1998). Several studies agree that an increasing SNFW improves the efficiency of the buffer effect (Brosofske et al., 1997; Little et al., 2015). However, in our study, with the exception of nitrate, all of the evaluated catchments had a similar response magnitude, which was irrespective of the SNFW. Thus, our hypothesis was not fulfilled. This could be due to the narrow range of riparian widths available (14.8-22.5 m), given that RC1 could not be considered in the analysis because its pattern of variation differed from the other catchments, and RC6 was the control.

The studied watersheds were logged in the 1990s when the current regulations were not explicit regarding the maintenance of buffer zones with a specific width (Decreto Ley 701/1974, Law 18959/1990; Romero et al., 2014). This explains why no wider SNFWs were observed in the study zone. Presently, the Chilean regulations require a 5-30 m width, depending on the stream cross section and the terrain slope, and include strips that must not be intervened in addition to areas with limited management (Diario Oficial, 2011).

Most nutrients were lost at higher rates than before harvest, even in the presence of a streamside native forest, and at higher rates than in the control watershed, casting doubts on the effectiveness of this mitigation practice. Our results support Little et al.'s (2015) finding in this same study site, where they determined that $22 \mathrm{~m}$ was not enough for nitrate concentration to be comparable to a reference watershed with c. 100\% native forest. According to Little et al.'s (2015) study, a SNFW of 36 m could adequately filter some sediment fractions and nutrients. Therefore, our results support claims for a higher SNFW than that which can be applied according to the Chilean law.

\section{Concluding remarks}

A combination of monitoring several watersheds before/after disturbance and a comparison with a non-disturbed watershed proved useful to document changes in stream quality (nutrients and sediments) caused by fertilization and harvest of exotic Eucalyptus plantations. An effect associated with the moment of fertilization was observed immedi- 
ately following nutrient addition during a rainy period, but over the long-term, no significant effect was observed. In contrast, clearcutting released substantially more nutrients than those detected in the control watershed, during a longer time period. Sediments did not present a strong pattern in response to harvest compared to the control. Most change was attributed to the rise in discharge produced by rain increasing from one year to the next, and mainly by the increase of the rainfall/runoff coefficient due to plantation clearing.

Streamside native forest width played no role in differentiating the response of watersheds. In addition, our results suggest that SNFW under $22 \mathrm{~m}$ are not enough to avoid the extra nutrient losses associated with harvesting, as they do for sediments, and support claims for wider widths.

This study monitored five watersheds throughout a four-year period and therefore constitutes an improvement to classical paired watershed studies that only use two catchments.

\section{Acknowledgements}

JC would like to thank Fondecyt for their funding via the grant no. 1085024. CL and AL give thanks to the Fondo de Investigación de la Ley de Bosque Nativo 023-2010 and FONDAP. We also thank Matías Calvo, Paul Dassori, Pedro Hervé, Leonora Jarpa, Iván Railaf, and especially Rodrigo Bravo for their support in the field, laboratory work, and data processing. Prof. Juan Schlatter helped us with the fertilization recommendations. MASISA S.A. and Alfredo Almonacid made the necessary arrangements for the clear-cut operations. We appreciate the support of The Nature Conservancy for permission to work within their property. Finally, we would also like to acknowledge the valuable comments made by the anonymous reviewers.

\section{References:}

Alfaro, M., Salazar, F., Iraira, S., Teuber, N., Villarroel, D., Ramírez, L. 2008. Nitrogen, phosphorus and potassium losses in a grazing system with different stocking rates in a volcanic soil. Chil. J. Agric. Res. 68, 146-155.

APHA (American Public Health Association). 2005. Standard Methods for examination of water and wastewater. 21st ed. American Public Health Association, Washington, D.C., USA, 1263 p.

Baillie, B.R., Neary, D.G. 2015. Water quality in New Zealand's planted forests: a review. Nz. J. Forestry Sci. 45, 7-24.

Bateman, A.S., Kelly, S.D., Jickells, T.D. 2005. Nitrogen Isotope Relationships between Crops and Fertilizer: Implications for Using Nitrogen Isotope Analysis as an Indicator of Agricultural Regime. J. Agric. Food Chem. 53, 5760-5765.

Beltran, B.J., Amatya, D.M., Youssef, M., Jones, M., Callahan, T.J., Skaggs, R.W., Nettles, J.E. 2010. Impacts of Fertilization on Water Quality of a Drained Pine Plantation: A Worst Case Scenario. J. Environ. Qual. 39, 293-303.

Boothroyd, K.G., Quinn, J.M., Langer, E.R., Costley, K.J., Steward, G. 2004. Riparian buffers mitigate effects of pine plantation logging on New Zealand streams: 1. Riparian vegetation structure, stream geomorphology and periphyton. Forest Ecol. Manag. 194, 199-213.

Brosofske, K.D., Chen, J., Naiman, R.J., Franklin, J.F. 1997. Harvesting effects on microclimatic gradients from small streams to uplands in western Washington. Ecol. Appl. 7, 1188-1200.

Bruijnzeel, L.A. 2001. Hydrology of tropical montane cloud forests: a reassessment. Land Use and Water Resource Research 1: 1-18. 
CIREN (Centro de Información de Recursos Naturales). 2001. Estudio Agrológico X Región. Tomo I. Serie Hueycolla. CIREN, Santiago, Chile, 200 p.

Cuevas, J.G., Soto, D., Arismendi, I., Pino, M., Lara, A., Oyarzún, C. 2006. Relating land cover to stream properties in southern Chilean watersheds: trade-off between geographical scale, sample size, and explicative power. Biogeochemistry 81 , 313-329.

Diario Oficial de la República de Chile. 2011. Reglamento de Suelos, Aguas y Humedales de la Ley 20.283. Viernes 11 de Febrero de 2011. Cuerpo I: $1-3$.

Fleige, H., Beck-Broichsitter, S., Dörner, J., Goebel, M.-O., Bachmann, J., Horn, R. 2016. Land use and soil development in southern Chile: Effects on physical properties. J. Soil Sci. Plant Nut. 24, 818-831.

Folk, R. 1980. Petrology of Sedimentary Rocks. Hemphill Pub. Co., Austin, Texas, 184 p.

Frêne, C. 2010. Efecto inmediato de la práctica silvícola de tala rasa en plantaciones forestales de Pinus radiata sobre el caudal y transporte de sedimentos a escala de microcuenca, Cordillera de la Costa, región del Bio Bio, Chile. Master thesis. Universidad Austral de Chile, Valdivia, Chile, 83 p.

Hedin, L., Armesto, J., Johnson, A. 1995. Patterns of nutrient loss from unpolluted old-growth temperate forests: evaluation of biogeochemical theory. Ecology 76, 493-509.

Huber, A. 2009. Impact of clearcutting on water quality and quantity. In: P. Donoso (ed). Tala Rasa: Desafíos y Perspectivas. Universidad Austral de Chile, Valdivia, Chile, pp: 35-38.
Huertas, J., Cuevas, J.G., Paulino, L., Salazar, F., Arumí, J.L., Dörner, J. 2016. Dairy slurry application to grasslands and groundwater quality in a volcanic soil. J. Soil Sci. Plant Nutr. 16, 745-762.

Huygens, D., Boeckx, P., Templer, P., Paulino, L., Van Cleemput, O., Oyarzún, C., Müller, C., Godoy, R. 2008. Mechanisms for retention of bioavailable nitrogen in volcanic rainforest soils. Nat. Geosci. $1,543-548$

IPCC. 2007. Climate Change: The Physical Science Basis: Contribution of Working Group I to the Fourth Assessment Report of the Intergovermental Panel on Climate Change: S. Solomon, D. Manning, Z. Chen, M. Marquis, K.B. Averyt, M. Tignor, H.L Miller (eds.). Cambridge University Press, Cambridge, United Kingdom and New York, NY, USA, 996 p.

Iroumé, A., Mayen, O., Huber, A. 2006. Runoff and peak flow responses to timber harvest and forest age in southern Chile. Hydrol. Process. 20, 37-50.

Jones, J., Almeida, A., Cisneros, F., Iroumé, A., Jobbágy, E., Lara, A., Lima, W.d.P., Little, C., Llerena, C., Silveira, L., Villegas, J.C. 2016. Forests and water in South America. Hydrol. Process. 31, 972-980.

Little, C., Cuevas, J.G., Lara, A., Pino, M., Schoenholtz, S. 2015. Buffer effects of streamside native forests on water provision in watersheds dominated by exotic forest plantations. Ecohydrology 8, 1205-1217.

Lowrance, R. 1998. Riparian forest ecosystems as filters for nonpointsource pollution. In: M. L. Pace, P. M. Groffman (eds). Successes, limitations, and frontiers in ecosystem science. Springer, New York, USA, pp: 113-141. 
Meyer, C. 2016. Recuperación de las funciones de almacenamiento y conducción de agua y aire del suelo bajo bosque con diferentes intensidades de uso en la Reserva Costera Valdiviana (RCV). Master thesis in Soil science. Faculty of Agricultural Sciences, Universidad Austral de Chile, Valdivia, Chile, 63 p.

Perakis, S., Hedin, L. 2002. Nitrogen loss from unpolluted South American forests mainly via dissolved organic compounds. Nature 415, 416-419.

Pérez, C., Hedin, L., Armesto, J. 1998. Nitrogen Mineralization in Two Unpolluted Old-Growth Forests of Contrasting Biodiversity and Dynamics. Ecosystems 1, 361-373.

Pérez, C., Carmona, M., Armesto, J. 2003. Non-symbiotic nitrogen fixation, net nitrogen mineralization and denitrification in evergreen forests of Chiloé Island, Chile: a comparison with other temperate forests. Gayana Bot. 60, 25-33.

Quinn, J.M., Boothroyd, I.K., Smith, B. 2004. Riparian buffers mitigate effects of pine plantation logging on New Zealand streams: 2. Invertebrate communities. Forest Ecol. Manag. 191, 129-146.

Quinn, J.M., Cooper, A.B., Davies-Colley, R.J., Rutherford, J.C., Williamson, R.B. 1997. Land use effects on habitat, water quality, periphyton, and benthic invertebrates in Waikato, New Zealand, hill-country streams. New Zeal. J. Mar. Fresh. 31, 579-597.
Quinn, J.M., Wright-Stow, A.E. 2008. Stream size influences stream temperature impacts and recovery rates after clearfell logging. Forest Ecol. Manag. 256, 2101-2109.

Rodgers, M., O'Connor, M., Robinson, M., Muller, M., Poole, R., Xiao, L. 2011. Suspended solid yield from forest harvesting on upland blanket peat. Hydrol. Process. 25, 207-216.

Romero, F., Cozano, M., Gangas, R., Naulin, P. 2014. Zonas ribereñas: protección, restauración y contexto legal en Chile. Bosque 35, 3-12.

Sernageomin (Servicio Nacional de Geología y Minería). 1982. Mapa Geológico de Chile escala 1:1,000,000. Santiago, Chile.

Thompson, R.M., Phillips, N.R., Townsend, C.R. 2009. Biological consequences of clear-cut logging around streams-Moderating effects of management. Forest Ecol. Manag. 257, 931-940.

Winkler, R., Spittlehouse, D., Boon, S. 2017. Streamflow response to clear-cut logging on British Columbia's Okanagan Plateau. Ecohydrology DOI:10.1002/eco.1836. 